\title{
硫酸水溶液中でのアルミニウムの 交流電解における浴電圧の影響
}

\author{
佐 藤 敏 彦* 常 盤 武 史 ${ }^{*}$ \\ Effects of Bath Voltage on Current Wave Forms during \\ AC Anodizing of Aluminum in a Surfuric Acid Solution
}

Toshihiko SATO* and Takeshi TOKIWA*

\section{1. 緒言}

硫酸水溶液中でアルミニウムを交流電解する時, 浴電 圧の違いにより電流波形が変化したので，以下に報告す る。なお， 非対称交流電圧及び交直重畳電圧による電解 についても実験した。

\section{2. 実験試料及び方法}

アルミニウム試料は純度 $99.5 \% \mathrm{Al}$ のアルミニウム板 $(1 \times 5 \times 0.03 \mathrm{~cm})$ を $5 \mathrm{wt} . \%$ 水酸化ナトリウム水溶液 $\left(70^{\circ} \mathrm{C}, 20\right.$ 秒間）中で前処理して用いた。対極は白金 板 $(5 \times 20 \times 0.2 \mathrm{~cm})$ を用いた。電解浴は $15 \mathrm{wt} . \%$ 硫酸水 溶液を用いた。交流電解, 交直重畳電解及び非対称交流 電解は扶桑製作所製交流電解装置を用いて行なった。交 流電圧の周波数は $50 \mathrm{~Hz}$ とした。電解電流は電解開始 3 分後のリサジュー図形で測定した。なお，電解開始20〜 30秒後に電解電流は定常状態になる。リサジュー図形測 定は黒田 ${ }^{1)}$ 同様の方法により行なった。交流電解中の 浴電圧と電解電流をそれぞれシンクロスコープ上の横軸 及び縦軸に入力した。

\section{3. 実験結果}

硫酸水溶液中でアルミニウムを交流電解すると, リサ ジュー図形はだ円図形とアノード・ピーク電流及びカソ ード・ピーク電流の合成図形になる1)。だ円図形は電解 系の容量電流である2)。図 1 は交流電解の浴電圧の違い による容量電流 (シンクロスコープ上に現われる傾斜だ 円の最大值), アノード・ピーク電流及びカソード・ピ 一ク電流の変化を示す。容量電流 $\left(i_{\mathrm{NF}}\right)$ は浴電圧の増 加に対して直線的に増加している。容量電流は交流電解 により形成された酸化皮膜のバリヤー層厚さに関係づけ られるので, 交流電解皮膜のバリヤ一層厚さは電解電圧 に正比例していることがわかる。アノード・ピーク電流

* 芝浦工業大学 (下108 港区芝浦 3-9-14)

Shibaura Institute of Technology 3-9-14, Shibaura, Minato-ku, Tokyo 108 $\left(i_{\mathrm{a}}\right)$ とカソードピーク電流 $\left(i_{\mathrm{c}}\right)$ の比は浴電圧により 変化している。浴電圧が低い時はアノード・ピーク電流 がカソード・ピーク電流より小さいが，浴電圧が $6 \mathrm{~V}$ 以 上になるとアノード・ピーク電流よりカソード・ピーク 電流が小さくなる。10V以上では再びカソード・ピーク 電流がアノード・ピーク電流より大きくなる。浴電圧の 増加によりアノード・ピーク電流とカソード・ピーク電 流が同じ割合で増加はしない。この理由は交番電場下で のアノード電圧一ーアノード電流の分極曲線 $\left(\eta_{\mathrm{a}}-i_{\mathrm{a}}\right.$ 曲 線) とカソード電圧一一ソード電流の分極曲線 $\left(\eta_{\mathrm{c}}-\right.$ $i_{\mathrm{c}}$ 曲線）が同じでないからである。

非対称交流電圧でアルミニウムを硫酸水溶液中にて電 解して,アノード電流に対するカソード電圧の影響を検 討した。図 2 はアノード電圧 (最大值) を10V一定にし

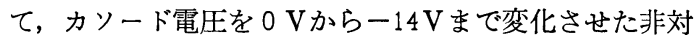
称交流電圧でアルミニウムを電解した時のアノード・ピ 一ク電流とカソード・ピーク電流を示す。図 2 に扣い て, カソード電圧0 Vでのアノード電流は単相半波整流 電圧によるアルミニウム陽極酸化の電流を表わす。図 2 でカソード電圧ー $10 \mathrm{~V}$ の時は, $10 \mathrm{~V}$ の対称交流電圧に相 当する。非対称交流電圧に拈いて, カソード電圧がアノ ード電圧 (10V一定) より小さい時, アノード電流すカ ソード電流も小さくなる。アノード電圧が小さいのでカ ソード電流が小さくなるのは当然であるが, アノード電

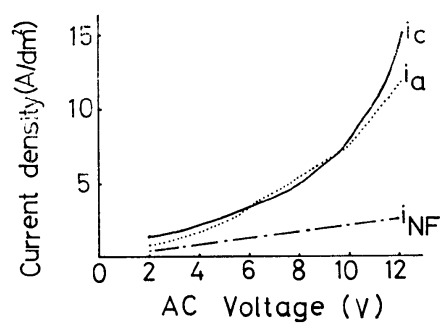

Figg. 1 Capasitive current, anodic peak current and cathodic peak current during electrolysis of aluminum by symetric alternating voltage in a sulfuric acid solution. 


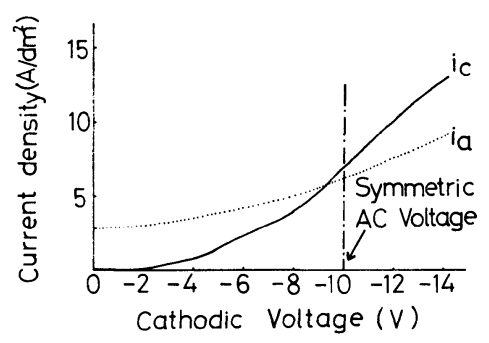

Fig. 2 Anodic peak current and cathodic peak current during electrolysis of aluminum by unsymetric alternating voltage in a sulfuric acid solution.

流が減少するのはカソード電圧の減少によりアノード反 応速度が抑制されることを意味している。アノード電圧 よりもカソード電圧が大きい非対称交流電圧の時はア， 一ド電流もカソード電流も大きくなる。カソード電圧が 増加したのでカソード電流が大さいのは当然であるが, アノード電流の増加は大きいカソード電圧がアノード反 応速度をさらに促進していることを意味する。図 2 の実 駼結果より, 交流電圧によるアルミニウム陽極酸化の場 合, カソード電圧は陽極酸化反応を促進していることが わかる。そして陽極酸化反応促進の度合はカソード電圧 が大きいほど，大きいこともわかる。なお，アルミニウ ムの交流電解着色に扣いて, カソード電圧を一定にし て, アノード電圧を減少させると, カソード電流は減少 した ${ }^{3)}$ 。交流電解に拈いてはアノード電压とカソード電 圧がアノード電流とカソード電流にそれぞれ相互作用を 及ぼしていることがわかる。

図3は交直重嘼電压でアルミニウムを硫酸浴中にて電 解した時のアノード・ピーク電流とカソード・ピーク電 流を示す。交流電圧は $10 \mathrm{~V}$ 一定として, 重畳する直流了 ノード電圧は０Vから10Vまで変化させた。直流アノー ド電圧を重畳するとカソード電流は減少した。アノード 電流は重畳したアノード電圧が８Vまでは電流が増加し たが，重畳電圧が８V以上になるとアノード電流は減少 した。一定の交流電圧に直流アノード電圧を重畳すると カソード電圧は減少するので, カソード電流が減少する のは当然である。しかし, カソード電流の減少度合が大

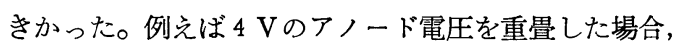
カソード・ピーク電圧はー6Vであるが, カソード・ピ 一ク電流は注とんどゼロであった。直流アノード電圧を

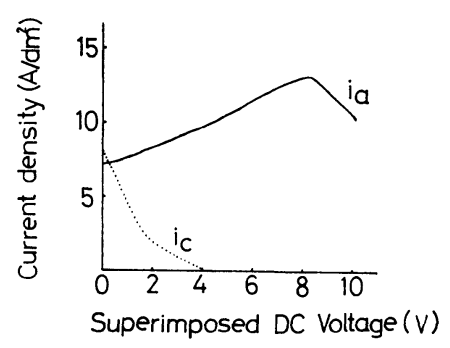

Fig. 3 Anodic peak current and cathodic peak current during electrolysis of aluminum by direct-alternating superimposed voltage in a sulfuric acid solution.

重畳するとアノード・ピーク電圧は大きくなるので，ア ノード電流が大きくなるのは当然である。例兄ば重畳す る直流アノード電圧が $2 \mathrm{~V}$ の時, 交直重畳電圧のアノ一 ド・ピーク電圧は12Vになるので, アノード電流は10V の対称交流電圧の時のアノード電流よりも大きくなる。 しかし，アノード・ピーク電圧 $12 \mathrm{~V}$ の交直重疊電圧によ るアノード電流よりも $12 \mathrm{~V}$ の対称交流電圧によるアノー ド電流のほうが大さかった。この原因は前者の場合はカ

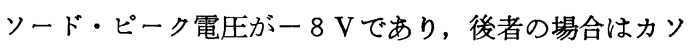

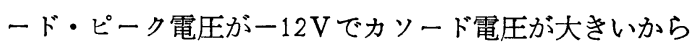
である。

図 3 亿怙いて, 重畳する直流アノード電圧が $10 \mathrm{~V}$ の時 はアノード電流が減少してきた。より大きいアノード・ ピーク電圧にもかかわらずアノード電流が減少したのは カソード電圧の影響である。重畳する直流アノード電压 が10Vの時はカソード電圧が０Vである。非対称交流電 圧でカソード電圧が小さい時にアノード電流が減少した のと同じ理由である。交直重畳電圧による電解の場合す アノード電流の大きさはアノード電流の大きさだけで決 定されるのではなくて, カソード電圧の影響をうけてい る。

(1978-2-9 受理)

\section{文献}

1) 黒田孝一；アルミニウムバリヤ一層の等価回路によ る研究, 電気化学, 39, 93 (1971)

2 ) 雀部俊樹, 秋山明胤, 佐治孝; 交流電解に上る陽極 酸化アルミニウムの着色, 本誌, 27, 531 (1976)

3) 佐藤敏彦, 日野根紊; アルミニウムの交流電解着色 に拈けるアノード電圧の影響, 本誌, 28, 181 (1977) 